\title{
The Diversity of Internet Memes Interpretations: A Discourse Analysis of Incongruity of Popular Memes Made by Indonesian Netizen
}

\author{
Rizky Anugrah Putra*, Sulis Triyono \\ Yogyakarta State University, Karang Malang, Jl. Colombo No.1, Caturtunggal, Kec. Depok, Kabupaten Sleman, Daerah Istimewa \\ Yogyakarta 55281
}

A R T I C L E I N F O

\begin{abstract}
A B S T R A C T
In the modern era, human has varied ways to communicate, interact, and express ideas. Using memes is one of contemporary human approaches to sending messages. However, similar to language, they have linguistics rules which have to be obeyed by the user. Memes also have its binding codes which are accepted by the memetic communities. This study is intended to reveal how widespread memes are violated by the netizen since there are diversities in using memes within Indonesian internet communities. To expose the violation phenomenon, the multimodal approach is conducted by using discourse analysis and social semiotics (Chandler, 2013) which focus on observing the visual and textual aspect of favorite memes. The paper claimed, that most of the Indonesian internet communities often force memes and use them in an inappropriate context.
\end{abstract}

\author{
Paper type: \\ Research Article \\ Article history: \\ Received 16 November 2017 \\ Revised 2 August 2018 \\ Accepted 29 August 2018 \\ Keywords: \\ - discourse analysis \\ - social semiotics \\ - memes
}

\section{Introduction}

Richard Dawkins proposed the origin of memes in his term "meme." This term associated with the fundamental theory of self-replicating unit of cultural transmission which deals with imitation (Chandler, 2012). The internet users often assume that this term refers to the combination of phrases and images which are produced to make funny jokes or usually to criticize recent social phenomenon. Dawkins (2006) asserted that meme is an idea which takes the form of behavior, lifestyle, belief, fashions, etc., which is imitated and propagated to be diffused from one to another individual within social culture or subculture through interaction by using several media, such as writings and photographic images.

Moreover, Oxford online dictionary also defines this cultural artifact as "image macro" which signifies the particular usage of photographic image and catchphrase to evoke the humorous effects. Memes are also considered as a form of digitization from the participatory culture of the internet. Therefore, memes can be redone and used as a new form of communication (Shifman, 2014). This communication is formed creatively and spread independently. For example, a creator will create a meme on social networking sites and the memes will be commented by netizens using other memes containing various captions which match the context. Meme creators make their meme from picture and two line of text which is located in upper side of the image which has functioned as the set-up, and the other text is found at the bottom of the image which is operated as the punch line. Besides, Brunnello \& Juliana (2012) emphasized that memes are not merely a simple mimetic since

\footnotetext{
${ }^{*}$ Corresponding Author.

E-mail Addresses: rizky.anugrah2016@student.uny.ac.id (R.A. Putra), sulis@uny.ac.id (S. Triyono)
} 
they have a memetic element which play a role as an element of imitation. The memetic elements are evolved uniquely through several processes of natural selection.

\subsection{Meme as cultural transmission}

Dawkins (2006) writes that meme is based on how the biological units survive and how those unit are extinguished in the natural selection which associates with the genetic transmission. However, it had been noted that the natural strategy of surviving could be evoked through non-genetic methods. These methods include language, custom, ceremonial practices, art, and architecture. Dawkins also emphasized that non-genetic methods have nothing to do with gene and genetic transmission process; as a result, he claimed that memes relate to the cultural transmission.

Moreover, the example of memes proposed by Dawkins relates to the idea, tunes, catch-phrases, clothes fashions, and building arches. The reason behind the technical term decision is related how the term gene has a resemblance to the root word "mimeme" derived from Greek which means 'something that is imitated.' Since the word 'imitate' is the key word relating to the notion of the meme, Dawkins assumed that memes disseminate themselves in society.

The memes disseminate from mind to mind which means the spreading process is involving the imitation process. When individual induces memes in another thought, he indirectly 'parasitizes' his brain, and turns the others into the medium of memes propagation. However, even meme can be replicated through imitation, and there are three qualifications which determine whether memes can survive or not in social context. Dawkins writes that the qualification relates to longevity, fecundity, and copying-fidelity aspect (Chandler, 2012).

Longevity is the duration of the ideas about memes that survive in someone's minds. Similar to book, as long as the memes still linger on someone's brain, they can be reproduced through imitation. Fecundity relates to how the idea is spread within the social group. For example, the catchy jargon from an advertisement can be considered to be of high fecundity if it spreads and it is remembered by many people. Therefore, copyingfidelity relates to how the meme can resist the alternation process when it is imitated and transmitted from one person to another. The term alteration here refers to how the memes still keep the original substance without being altered in the process. Similar to information, the message in the meme can be altered if the info is transmitted from person to person.

Blackmore (1999) develops Dawkins's idea related to memetic transmission. There are several terminologies which are proposed related to the distinctions between the imitator or replicators and the vehicles. Replicator refers to anything which makes the memetic copies and the vehicles refer to the medium which interacts with the social environment. Vehicles act as the protector which carry the replicator which insulates it from the social alternation.

Blackmore writes that every knowledge which is gained through imitation is the meme; however, perception and emotional state are not considered as memes since they cannot easily be passed to others. The decisions about what to imitate are regarded as imitation which has complex transformation in perception and physical action.

Distin (2005) defined memes as the unit of information which gained from the society which has representation content which is considered as the cultural equivalent. Language is considered as one of the representational systems, so memes can be considered as a linguistic unit because it involves a linguistic aspect, i.e. words. Language represents the meme as the whole idea of the concept, but the decision is up to the society that decides to reject or accept the proposed notion expressed in the words.

Concerning several concept and belief of the previous expert who have conducted research, memes have a significant impact on cultural and social evolution. Distin admitted that cultural development is an aspect which cannot be entirely controlled since it has the autonomous process. Moreover, human cognition is the mechanism which designed to learn because of that it always evolves and expands its potency beyond the individual will.

\subsection{Meme and Social Media}

Similar to social culture, the internet also has the culture which always mobilizes and evolves. Internet culture and society defines the term 'meme' as the particular netizen cultural artifacts (Chandler, 2012). In the modern era, video becomes the convenient communication tools, and people prefer to use it to send ideas and concepts 
which can linger in someone's minds. This principle is used by advertisers to introduce their product by using the "infectious ideas" to affect subconscious part of the human mind.

Moreover, memes have several roles in internet social interaction which will be elaborated further. Firstly, memes act as a medium of communication. Similar to language, in internet culture, people often substitute the word by using memes. This approach is effective and viral since the substance can be understood by the communicatee in a convenient way. Second, memes are the vehicle to transmitted idea, knowledge, and propaganda. The fact that memes can facilitate us to deliver meaningful input which can be processed into knowledge. Memes can easily be accepted by internet society despite the information contained. However, since memes convince internet society, several people in particular capacity use meme to send distrust, to alter the truth, and to bring conflict within society.

Lastly, memes act as the cultural marker since they represent the cultural background where those memes are used. However, relating to the meme usage, there are codes which are established by memetic society regarding the proper way to use memes. Based on Know Your Meme online database, there are many distinctions how to use some particular memes. To avoid the misuse of certain memes, the memetic society has universal rules in using memes; they are relevancy, originality, and comfortability.

The relevancy aspect is fulfilled when the creator or meme maker creates a meme which is relevant to the meme function, for example, Chuck Norris Facts meme. In memetic society, this meme reflects that fact Norris has abilities to do anything since he is considered as invincible heroes due to his manliness.

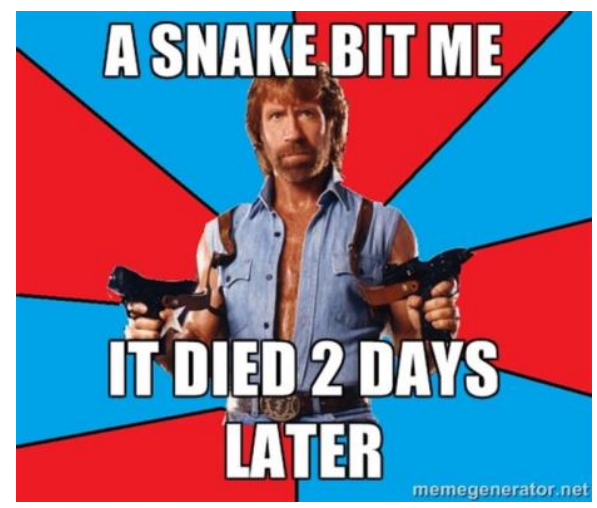

Figure 1. Chuck Norris Fact Meme (taken from memegenerator.net)

It can be concluded from the meme above that even venomous snake cannot hurt Norris, and it dies several days later due to his manliness. His manliness acts as the reason for reversional effect.

Based on the example above, memes have several functions and should be followed by the meme creator to fulfill the relevancy aspect. If someone uses the Norris picture and merely puts random caption without knowing the purpose, it is considered as the violation of the meme function.

Originality aspect involves how the meme creator reproduces the memetic photographic image by using his/her idea. The idea is reflected in the phrase or the caption. Thus, it is acceptable to reproduce the similar memetic image, but the catch-phrase should be different based on the creator's idea. However, meme creator can use new photographic image based on film, comic, videos, and other audio-visual media, but to become a new photographic meme it should be accepted by the memetic society and relevant to the present phenomenon. A meme creator cannot force a meme by using a random picture unaccepted by the community.

The last is comfortability. In memetic culture someone is not allowed to provide disturbing image, such as gore, pornography, sadistic behavior, and disgusting picture. Inappropriate pictures of memes have to be labelled Not Safe For Work (NFSW) tag. The memetic community has provided specific places for these genres. Several classifications were made for memes which contain sensitive material, so that the NFSW tagged memes are not mixed with humorous memes.

By following the memetic rules, someone can utilize themselves to understand the memetic culture and also to be accepted by the memetic society. However, if someone violates the specific code of memetic culture, it can reflect that they do not entirely understand or they are not from the memetic community.

Moreover, individual which create memes irrelevantly or just follow the mainstream culture in meme usage will be claimed as "normies." Normies only recognize popular meme because the majority of internet users 
make it accessible, but when they face particular memes, they often do not know the exact function of the memes.

In Indonesia, memes are incredibly popular and have several virtual societies, which often contributes their idea in the form of photographic memes. Most of the memes are intended for humorous purpose. Several memes contain the satirical comments directed to the government or other recent phenomena. The majority of meme contributors in Indonesia are adolescences since they have high enthusiasm in contributing fresh ideas. However, these contributors often violate the universal principle of individual meme usage which alters the contributor's opinion about the particular meme.

Since there are incongruities made by Indonesian meme creators, the present study is intended to reveal the reason behind those anomalies since it is still vague whether the cultural diversity which triggers this phenomenon or merely the consequence of the ignorance of universal codes of memetic community. Moreover, the critical discourse analysis will be conducted to reveal what ideological assumption contained in the violated memes.

\section{Research Methods}

\subsection{Settings}

The researchers analyzed the Yao Ming's face, Mad Dog, and Really High Guy. There are a number of reasons why the researchers chose those memes. Firstly, those memes are frequently used by Indonesian netizen. Secondly, since the netizens often misuse those memes, the researchers wanted to know how they violated the meme functions.

Moreover, the researchers primarily collected 150 of memes from the memetic website and other such as ICAK.com, kaskus, memetic facebook group, etc. The researchers decided to choose those sites because most of the contributors are from Indonesia.

Moreover, from 150 memes, 75 were taken from the "fresh" section, and the rest were taken in the "legend" section. The researcher selected ten examples from 3 memes which had been analyzed from both parts.

\subsection{Procedure}

After collecting 150 examples of memes, the researcher classified these memes into four categories based on the function. The analysis process was begun by examining the images contained in the background to analyze the visual element of the meme. Explicitly, the researcher analyzed the visual aspect to reveal the ideological assumptions by carefully comparing the theme and phrase in image macro with the background image.

Moreover, the textual aspect of these memes was also investigated to provide exact reasons of how the concept and the language represent the ideological assumption. This method was also used to reveal the violation; this was conducted by comparing the substantial aspect of memes with the exact function of the memes.

\subsection{Analysis}

The suitable analysis method for this study is critical discourse analysis. The research elaborated several reasons for CDA. Since memes contain explicit and implicit ideological content, based on (Fairclough, 2003), CDA can be used to examine the language and its discursive practice to reveal deep meaning created by social, cultural, and political contexts. The researchers assumed that CDA could also be used to uncover the uniqueness of meme usage.

Moreover, there are several phases of analysis which were employed in the present research. First, the researcher inspects the visual element of Yaoming, Stanley Stoner, and Mad Dog meme in order to provide the detailed description of those image-macro contexts since the context in the meme is outside the text itself. Afterward, the researcher applied the Fairclough approaches in analyzing memes. The researcher employed three dimensions of critical discourse analysis, namely microstructural, meso-structural, and macrostructural. In the microstructural aspect, the researchers focused on aspects of cohesion, coherence, and grammar. While on the meso-structural aspect, the researchers reviewed the dissemination and consumption process of the meme. Then in macrostructural, the researchers associated the diversity of memes with sociocultural aspects. 


\section{Result and Discussion}

The analysis of selected memes was presented in the following section. First, the researcher examined the visual element from chosen memes based on visual semiotic categories. The second phase of analysis inspects the textual content of those memes.

\subsection{Visual semiotic element}

Based on Know Your Meme website, the Yao Ming's face which sometimes assumed as "Fuck That Guy" is the photographic image or comic-style contour drawing of Chinese basketball player Yao Ming which ridiculously smiles. This meme is used to express the dismissive reaction towards someone else's opinion or input in online discussion.

The Yao Ming's face meme template is the image of Yao Ming, a professional basketball player. The picture is taken from press conference videos when he was laughing. His eyes are closed, and his smile is broad exposing his upper and lower teeth. The background landscape is blurred NBA wallpaper.

Yao Ming's facial expression depicts feelings of hilarity. However, this meme conveys different cultural symbol based on the community. Memetic community assumed this meme as the supercilious comment towards someone's opinion to compete them by putting better idea.

Besides, Yao Ming's memes have several cultural symbols which are presented by the co-text "Bitch Please" in the 70's. This phrase was derived from prostitution community long before the internet was accessible which depict expression of disbelief and discomfort in that community. In contrary, memetic community combines this co-text with the Yao Ming's face image as the reflection of automatic respond toward a person who says something stupid and also to compete with someone argument which has dismissive quality.

Different from Yao Ming, Mad dog (Yayan Ruhian) is an original meme which is proposed by Indonesian internet society. Mad dog is the primary antagonist in Indonesian action movie entitled The Raid: Redemption, released in 2011. This meme has a nearly similar function to Chuck Norris Fact memes, but it describes someone who adores to attain more challenging activities to amuse himself as a courageous person.

This function is fixed based on The Raid movie. The Mad dog is a deadly fighter, insolently decided not to use his gun when he met Jaka (Joe Taslim), a SWAT team leader. He prefers using bare hands to using a gun since it is less challenging. In the movie, he said "tidak ada greget nya".

Moreover, the meme template is the photographic image of Yayan Ruhian using sweaty grey t-shirt and pants. The landscape background is the brown-and-white-stripe background. The Mad Dog image is located in the center of the image meme which is showing half of his body part from the head till his haunch. The pose of Yayan Ruhian suggests that he is ready for battle since his right arm is clenched and his eyes are staring sharply toward the camera. It can be assumed he was making eyes contact with the viewer of this meme. According to Machin and Mayr in (Chandler, 2012), when a person in the image gazes directly toward the viewer, it is considered as "demand images." It subconsciously asks the viewer of the picture; as a result, they believe that their existence is being recognized as if they are in the actual interaction. His body language conveys valiant attitude which confronts us to do the same thing. The Mad Dog meme image has several cultural symbols. Long hair and mustache is the symbol of violence which is often reflected by the hoodlum in Indonesia society. However, sometimes meme creator edits him with Silat battle stance, so it contained the cultural aspect of South Asian heritage.

The Know Your Meme website explains that the Really High Guy meme or Stoner Stanley meme is an image macro, which presents the picture of a man under the influence of marijuana. The caption of this meme depicts tipsy behavior, so that it will be giving an inappropriate answer. Additionally, in the meme template, the man is centered on the only figure visible. However, the viewer can only see the head until the shoulder since the image perhaps had been cropped by the editor. The man has fair reddish skin, which suggests that he is from western or European country. The landscape and the background of this meme is the yellow wall since probably the man is in the bedroom. He looks at the camera and smiling, but his eyes are glazed due to being intoxicated.

The cultural symbol in this meme is that marijuana is often used for recreational purposes by the adolescent in several developed countries. Based on the article in Quartz Media website shows that weed is legal in 30 states of USA. Most of them legalize the marijuana for medicinal purpose. However, eight of those countries legalize the marijuana for recreational use. 
Moreover, this meme also suggests us that in western country hedonistic lifestyle is often favorable and accepted by the society. Comparing this lifestyle to the South Asian nation, it is unacceptable since that is unsuitable with the particular norm, specifically in Indonesia.

\subsection{Microstructural}

In this study, the researcher used the traditional method of discourse analysis. However, the textual aspect of the memes is not easy to be examined by using this traditional method since the meme text consisted of sentence which did not have decent grammar or punctuation. After collecting 150 memes which contained Yao Ming, Mad Dog, and Stoner Stanley image macro, the researcher managed to examine the textual content from the meme samples. The researcher analyzed each meme and classified several categories based on the subject which the memes refer to in the theme or meme text. For example, the Yao Ming meme included "Education", "Religion", and "Society".

Moreover, the researcher also made the sub-division from the primary classification. For example, subclassification of "Education" specified whether the text and co-text refer referred to "Senior High School" or "University". The sub-classification facilitated the researcher to recognize topics which tended to be alluded to in the meme. Thus, the topic could reflect the current social situation confronted by the meme creator.

However, several memes might be counted in multiple categories based on the text and co-text and also context which is contained in the meme. For example, in Indonesian made Yao Ming meme with the text "ngumbar foto di sosmed saat lagi ibadah.../lu mau perbanyak pahala atau perbanyak like" would be considered as the "Internet Culture" and "Religion".

In this section, the researcher provides the example of transcription of Yaoming, Stanley, and Mad Dog memes which consist of two-catchphrases. However, there are several memes which could not be converted into transcription since they consist of a chunk of a word which needs an image-macro to make the reader understood the context. The transcriptions are elaborated as follow:

\subsubsection{The textual analysis of Yaoming meme}

a) Subject ellipsis:

(1) [Kamu] kalau pacaran itu sama cowo yang pas lulus gak corat coret seragam / seragam saja disayang dan dijaga [olehnya], apalagi kamu.

(2) [Saya] Boro-boro ikut uji nyali / Ngeliat orang pacaran saja [saya] sudah hampir mau kesurupan.

(3) Buat apa [anda] kuliah? Yang sudah sarjana saja banyak yang nganggur

(4) [Anda] Ga sempet ngerjain PR dirumah?

(5) akhirnya [saya] berotot juga.

(6) Kentut tidak berbunyi itu lebih kejam dari pembunuhan / karena [itu] dapat menyebabkan saling fitnah.

(7) Muka itu dirawat / [muka] bukan diedit.

(8) [Orang] Ngumbar foto di sosmed saat lagi ibadah di mesjid dengan caption "ramadhan ini gua mau jadi anak soleh"

b) Predicate ellipsis:

(1) [seseorang] [pergi] ke masjid cuma buat konsumsinya doang / ada? Banyak!

c) Object ellipsis:

(1) Kamu pernah pura-pura salah kirim SMS saat ingin kenalan [dengannya].

(2) Gue jarang punya waktu buat belajar / tapi sekalinya gue punya [waktu], gue tetap saja ga belajar.

d) Subsitution: Cewek itu dimana-mana manis, baik, lembut / Lain ceritanya kalau mereka sudah jadi milik kita.

e) Lexical cohesion

(1) Repetition: rumah, seragam makan, belajar, gue, mikirin, gebetan and kamu.

(2) Hyponym: Hewan - Belalang and kupu-kupu.

The researcher had identified several ellipses in the memetic catch-phrases. Those ellipses consist of three types namely subject, predicate, and object ellipses. Those ellipses mostly referred to personal pronoun "You" or 
"Me". The subject pronoun ' $l u$ ' was used in Yaoming memes to allude someone in a humorous way. In contrast, the content creator used the personal pronounce 'gue' in the catch-phrase to express their particular experience. Moreover, the predicate ellipsis was used when the content creator mentioned the context in the catch-phrase. For example, when the content creator mentions adverb of place, they tend to omit the predicate (go) since they believed that the reader could understand that reference.

What makes Indonesian memes unique are in the catch-phrases, the content creators often omitted the sentence subject. Arifin et al. (2012) mentioned that ellipsis is used to express an idea which can be comprehended by the certain community even though the writer did not provide a detailed information about the content. Thus, Ellipsis was used in the memes to express the common problem which was confronted by the millennial adolescences.

The researcher also identified that there are several reiteration markers in those memes. The words which were repeated more than once in each memetic creation are 'gue', 'kamu', 'belajar', 'makan', 'mikirin', and 'gebetan'. Those words are associated with adolescence conundrum. For example, the memes could relate to their struggle in the middle school life. Thus, the memetic site visitors are mostly adolescences since they prefer to access hilarious sites which relate to their daily experience.

The researcher intends to mention that the register which was used by the memetic community was nonstandard Bahasa Indonesia or Slang. The words such as 'gue', and 'lu' are used in the informal situation. Even though most of their catch-phrases were grammatically unacceptable, this kind of register is acceptable within the memetic community. Therefore, the content creator preferred to use non-standard Bahasa Indonesia to instill the idea in the mind of their audience.

Base on grammatical function, most of image macro memes in Bahasa Indonesia employs unusual patterns. The content creator omitted the subject in the sentences. For example, in the catch-phrase 'kalau pacaran itu sama cowo', the subject was omitted. Thus, the pattern only consists of predicate and object. The researcher believes that the use of sentence which does not have a subject is to accentuate the idea within catch-phrases without mentioning who is the speaker (Azar, 1999).

In the textual aspect of Yao Ming meme sample, there were 16 references to "Love"; 16 references to internet culture; 15 references to "Education", with three of these specifically referencing the high school memory and struggle; 10 references to "Social Interaction"; 4 references to "Gender Diversity"; 2 references to "Money and Wealth"; 3 references to "Health and Hygiene"; 3 references to "Politics" and one reference to "Violence". In addition, this meme often used personal pronoun such as "Gue", "Anda", and "Lu" which refers to reference which was outside the text. The researcher also found that there were 51 action verbs used in Yao Ming memes.

\subsubsection{The textual analysis of Stanley meme}

Ellipsis:

(1) [saya] digigit anjing/ [saya] langsung demam berdarah.

(2) Sambil nungguin ajan magrib / gue makan diwarteg biar [saya] kuat puasanya.

(3) [saya] Bela-belain bangun jam $7 /$ biar sahurnya gak kesiangan.

(4) Cintai ususmu / minum [-lah] cacing tiap hari.

In Stanley memes, the content creators also omitted the subjects which act as the cohesion marker. However, the image of Stanley stoner plays a role as the context. Thus, the memetic community could access the true meaning of the memes which depicts the absurdity of the Stanley himself which under influence of marijuana.

However, Stanley memes are not coherent for people who do not understand the memetic culture. For example, when someone gets bitten by the rabid dog, they would get infected by rabies. However, in the catchphrase, the content creator substituted rabies for the dengue fever. This catch-phrase was expressed in that way to evoke the comical situation. Therefore, that is the reason why the Stanley meme is incoherent.

In the textual context of Stoner Stanley memes, there were 11 references to "Food"; 9 references to "PopCulture"; 8 references to "Health and Hygiene"; 4 references to "Internet Culture" and "Education"; 3 references to "Animals", "Technology", "Religion", and "Sport"; and one reference to each "Disaster", "Nationalism", and "Automotive". There were 7 memes which were considered as miscellaneous. Therefore, it had been found that from 50 Stoner Stanley memes, there were 38 verbs which describe an action and there was 26 personal pronoun which acts as the subject such as "Gue" and "Saya". 


\subsubsection{The textual analysis of Mad dog meme}

Ellipsis:

(1) [saya] main badminton pakai raket nyamuk / biar greget.

(2) [saya] main volleyball pake durian / biar lebih greget.

(3) [saya] Nguras bak mandi pake sendok / biar greget.

(4) [saya] Ngepel banjir / biar greget.

(5) Sidang skripsi pake jasa Hotman Paris / biar greget.

Similar to the previous memes, the content creator omitted the subject from the catch-phrase since the Mad dog image represents the subject. Thus, people who do not familiar to the memetic community, could not understand the catch-phrase, unless they know the context which is represented by the image macro.

The catch-phrase patterns mostly consist of a predicate, object, and complement. Moreover, the Mad dog memes often use action verbs which involve challenging activity. The challenging activity reflects his masculinity which lets him make the impossible becomes possible for him. Consequently, the subject is less important to mention since the primary idea is the challenging activity itself.

To make the first catch-phrase is coherent with the next one, the content creator added the word 'biar' as the reference. Moreover, the word 'biar' is the coherent marker since if the word 'biar' is omitted, those catchphrases would lose their semantic relationship.

In the textual content of Mad Dog meme sample, there were 7 references to "food"; 6 references to "Sports"; 6 references to "Animals"; 6 references to "Health and Hygiene"; 5 references to "Internet Culture"; 4 references to "Automotive"; 3 references to "Education", "Religion" and "Disaster"; 2 references to "Technology" and "Family"; 2 references to "Crime and Violence", one references to "Love", "Music", and "Money and Wealth". Therefore, there were 8 references which categorized as misc. There was 41 verb which describes an action in Mad Dog meme, and there was no pronoun.

\subsection{Mesostructural}

The production process of Yaoming, Stanley, and Mad Dog memes in the internet meme community involves various elements of society. In the memetic community structure, there are two noticeable components namely the connoisseurs and the content creators. The researcher uses connoisseurs as a diction to depict this social component since they access the memetic community to enjoy the memes as an art. Meanwhile, the contributor acts as the agent to instill ideas through the cultural artifact. The most dominant contributor in Indonesian memetic society is an adolescence who is still enrolled in the high school. This is proven based on survey results conducted by the association of internet service provider of Indonesia (APJII) which showed that $49.52 \%$ internet users in Indonesia are a productive age citizen. They fall into the 19-34 age group (Usia Produktif Mendominasi Pengguna Internet - Databoks. n.d.). In adolescence period, a person has numerous creative ideas. But sometimes an adolescence's creative ideas conflict with the system that has been established. Thus, the millennial makes the memes of Indonesia violate the universal memetic code. The researchers realized that the diversity of the cultural artifacts was beautiful and remarkable, but in this study, researchers wanted to contrast how the memes should be used.

Then, because the internet is easy to be accessed at this time, it is easier for someone to create a meme by using a computer and even a mobile phone. The memes that have been made will be disseminated through social media and memetic forums. However, electronic media such as television is not used as a media to disseminate memes. However, memes often raise unique themes that appear on television such as talk shows, news, and advertisements. Then, in printed media, memes are rarely found if any memes are used for advertising purposes. The meme has a fast deployment capability because one can easily replicate a meme using a different idea. Because of this imitation process, the process of disseminating meme cannot be dammed.

For millennial generation, meme seems to be a primary need because besides meme brings fresh humor, memes also provide an access to the latest information about current events that become a trend in a particular social area. The researcher believes that memes are very effective in conveying certain information once again packed with a memorable comedy form. Therefore, the meme is not only accessed for recreational purposes because the meme can also be a means to spread an ideology or even propaganda. 


\subsection{Macrostructural}

The development of memes is situationally in line with current the social situations. Thus, memes are a convenient tool for conveying aspirations. The use of memes is not necessarily just to criticize situational things but memes can be used to criticize other memes. The several content-creators often criticized about how to use the meme without violating the rules. The researcher believes every culture in the world has its own rules. As in Indonesia, the use of Yaoming, Stanley, and Mad dog memes confont a long contention. One side believe that memes must be subjected to the global meme rules while others insist that the rule is not important because the essence of the meme reduplication process is the element of humor. Therefore, content-creators from Indonesia did not follow the rules which they initially agreed upon. Consequently, the meme in Indonesia has a different content and context. On the one hand, the meme rules play a role to form unique sub-cultures which are interesting to be learned. Thus, the codes and norm make a community unique.

\subsubsection{The contention about Yaoming Meme in Indonesian internet society}

There is contention relating the context and the function of this meme since in Indonesia memetic society, most of the meme creators do not obey the rules. The researcher had elaborated in the previous section that Yao Ming meme is used to express the dismissive reaction towards particular phenomenon, achievement, or idea. The data show that Yao Ming meme acts as the response of hilarity toward specific event which is reflected by the Yao Ming laugh expression in each meme caption. This circumstance often occurs in Indonesia memetic society. The meme creators always put the Yao Ming's face to show the comedic point of his post which evokes the instant jokes. Most of the jokes tell about love and high school moment, so by examining this, it can be concluded that most of the creator was adolescence.

However, Yao Ming's face meme violation is acceptable by the majority of Indonesian netizen. Most of them are "normies" who just follow the mainstream without knowing that there are memetic codes in creating memes. In several discussions, they said it is acceptable because "it is for fun only, why so serious?". That is why the progress rate of Indonesian meme artifact is slow-going since the creator just follow what is already popular and reproduce it.

Moreover, from the data, Yao Ming memes which was made by Indonesian meme creator contain many references to "Love" such as "di read saja sudah syukur/ apalagi direply". The content relating to love highly is popular in Indonesian memetic society. Brunello (2012) admitted that this kind of meme is an ironical selfcriticism which is produced in the form of self-mockery since the references were outside of the discourse which is the person with the common problem.

The references to "Education" and "Popular Culture" depicts us the conundrum of education in Indonesia right now relating to those aspects such as "untuk apa mikirin un/ un belum tentu mikin kita". That aspect often happens on the adolescences. Thus, the creator wants to propose this idea to the adolescence as the majority of internet user in memetic society.

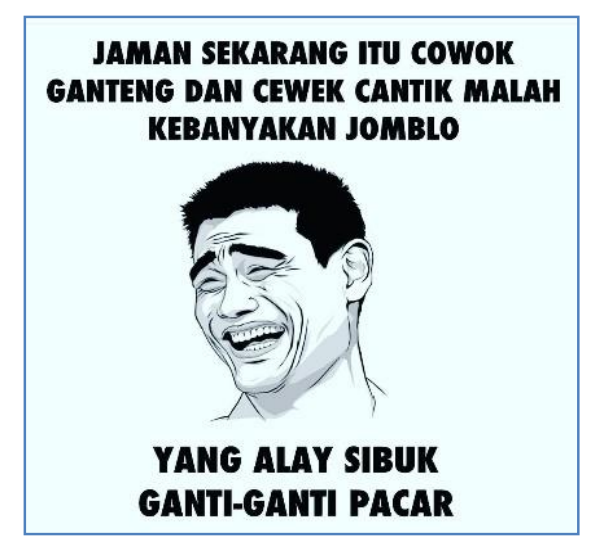

Figure 2. Yaoming meme made by an Indonesian creator (taken from 1CAK.com)

Regardless of that, it can be assumed that Indonesian meme creator tends to add the Yao Ming image to comment the popular phenomenon which is unsuitable in Indonesian society and also to describe the typical condition 
which is happened recently, mostly in the educational institution. Therefore, the creator used this meme to make satirical jokes relating to the peculiarities of the millennial generation which Brunello stated that this is a futile problem. Even the netizen knows there are the worst thing happening in their nation, they were actually enjoying this meme. It is also considered as ironic-satirical jokes which are produced in the form of image macro to reveal the diversity between the ideal of human expectation and the realities in the society Zijderveld cited in (Brunnello \& Juliana, 2012).

Moreover, an individual could identify or misunderstand this satirical humor. If the person shared particular background knowledge about the condition which is depicted in a meme, it will be a joke. In contrary, individuals will complain since they find it offensive. It will be considered as interesting, creative, or humorous based on the context, values and background knowledge (Brunnello \& Juliana, 2012) of the reader, so that it will give different impact to each respondent of meme.

\subsubsection{The contention about Mad Dog meme in Indonesian internet society.}

Although this meme is initially coming from Indonesia, it is still being misapprehended by most netizen and meme creators. From the data, it had been shown that sometimes particular creator makes the Mad Dog icon become someone who loves explosion and violence. It indicates that there is moral degradation within Indonesian internet society which is reflected from the meme as the cultural artifact.

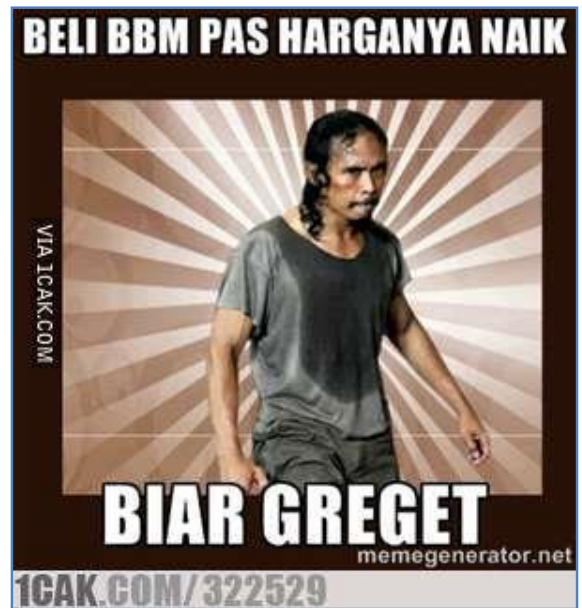

Figure 3: The model of Mad Dog meme which is accepted by the memetic community (taken from 1CAK.com)

Besides, Mad Dog memes formerly show and evokes the reader to not afraid to take a risk, but later, it is being misunderstood to become someone who loves violence. Therefore, the other evidence also showed that the creator just puts a random caption to evoke instant jokes, in fact, their jokes was senseless. For example, editing Mad Dog image macro with caption "Banci" or sassy in English to insult Chuck Norris.

However, based on the references of the memes, Indonesian meme creator tended to use Mad Dog meme to show challenging activities which are mostly relating to sport and food such as "main badminton pakai raket nyamuk/ biar greget" and "makan nasi lauknya lontong/ biar greget".

Moreover, the researcher also found that the Mad Dog meme has been being misinterpreted by the Indonesian netizen since many memes of Mad Dog did not describe challenging activity but more depicted suicidal intention for example "makan roti selainya lem alteco/ biar greget". It cannot be considered as valiant action but more reflect stupid and suicidal intention since super glue cannot be consumed and it is dangerous to human health. From the online discussion, many memes creator which understand the meme culture complains this type of image macro since it does not reflect the proper function of this meme or what they call "misused". Again, they complain was ignored since the majority of netizen accept this kind of meme usage.

\subsubsection{The contention about Stanley Stoner meme in Indonesian internet society.}

The Stanley Stoner meme shows the tipsy behavior of his. He was under the influence of Marijuana, so the catchphrase reflects improper answer. What the researcher found in Indonesian that they often make this meme 
to show him as brainless talker such as "digigit anjing/ langsung demam berdarah". This meme actually intended to become a one-liner joke but again this absurdity does make any sense at all.

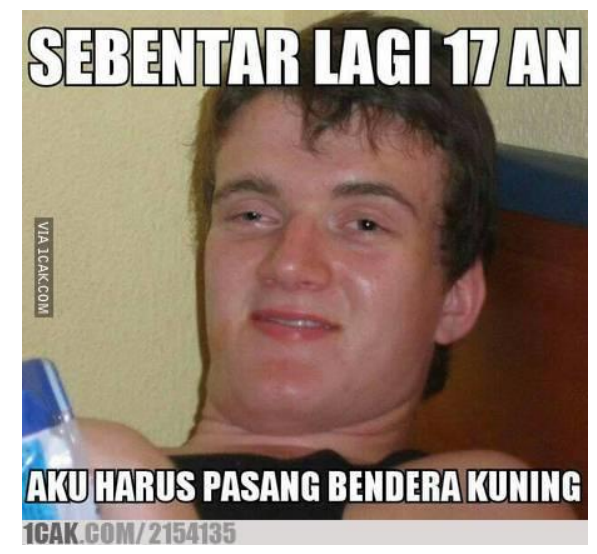

Figure 4: The model of Stanley Stoner meme accepted by the memetic community (taken from 1CAK.com)

Something unique in Stoner Stanley meme improper used in Indonesia is that it often collocates with "Segar Sari Susu Soda" which is a beverage product in Indonesia. Indonesian netizen often depicts him as drunkard because of that product. However, the product does not contain any alcohol. Some memes also show him being addicted to insecticide product. The behavior of Indonesian meme creator shows that there is cultural diversity since marijuana is illegal in their country so they substitute this to other familiar product to set one-liner joke and to make it more acceptable to the audience.

Moreover, Stanley was frequently made as a comic character which always says a non-sense thing. Many netizens especially adolescence find it funny even the usage is improper it is compared to the Know Your Meme description. It can be concluded the cultural diversity also create different assumption.

\subsubsection{Different sense of humor and social factors change the meme genre}

As humans, we often use humor as a means to facilitate the interaction process among human beings. We use humor for various purposes. For example, we can use humor to influence a person's mindset, to make others feel happy, to isolate and insult other social communities (Yip \& Martin, 2006). As a universal interaction phenomenon, humor has variations that are influenced by the culture of certain social communities that live in certain countries. Thus, every society in the world has a different way of expressing humor (Neil \& Erin, 2013). Erdodi \& Lajiness-O'Neill (2012) proved in their research that Americans tend to appreciate the aggressive and offensive humor. Meanwhile, the researcher found that Indonesian humor is focused on nonsensical comedy. Lesmana (2014) mentioned that absurdity in Indonesian humor is often found in children's interactions. Therefore, the researcher believes that the alteration in meme function which leans towards the aspect of absurdity is caused by the connoisseurs and content-creator who is still in the transition to maturity.

Since the majority of the meme is created based on English humor, it creates different interpretations in the audience whose culture is not English culture. English humor is fairly distinctive. The type of humor is dry, saying silly things in serious expression (wit). This witticism is often mixed with irony, sarcasm, and repartee. The witticism is a situation which is strange or hilarious because of somethings happen completely different from what we expect or the use of the word which express something different with the literal meaning such as "it is ironic if you die in the living room". Repartee is kind of clever jokes which is the quick answer in the conversation for example "Why piglets always feel ashamed/ because their mother is a pig". In Indonesia, this type of humor is not popular among adolescence since sometimes it is perceived as rude by an individual which is not familiar with it. Therefore, his fact is reflected in the 150 memes that had been observed and there is only a little evidence of this kind of jokes.

In contrary, Indonesian humor shows more slapstick and non-sense. Being expressive in both language and gesture is typically emphasized in Indonesian humor. Absurdity is the key characteristic of Indonesian humor, and this is often reflected in such a question as "Biji, biji apa yang nempel di tembok?/ Bijinya Spiderman".

Facial expression is also a key factor in Indonesian comedy. Comedians often make a parody. In addition, some comedians jest by insulting others' physical appearances; this kind of humor are not popular in this era 
since people consider this kind of jokes rude and improper. Consequently, the content-creators try to adjust the memes they make to be accepted in Indonesian society. It is a deliberate cultural adaptation to meet market demand (Ali, Karen, \& Sanders, 2003). Therefore, some Yaoming, Stanley, and Mad Dog memes sometimes go beyond their true function.

Furthermore, the diversity in meme usage is not only caused by the ignorance of original function of the meme but also the meme creator tries to adapt the meme to become more acceptable in particular memetic society based on cultural background and preference of humor in a specific community. Thus, what Distin (2005) had suggested that memes are unit of information which are obtained from society is qualified with the result since the diversity of the usage to make the idea which is presented in the form of memes equivalent with the specific social environment. The decision is up to the memetic society whether they want to accept the idea or not. For this reason, the memetic development cannot be entirely controlled by binding code since it will expand and evolves beyond human control.

If the idea is acceptable the meme will linger longer in society and it will be reproduced and spread by other individuals. It is similar to the memetic qualification which had been discussed by Chandler at the previous section which determines whether the social artifact can survive or not in social context. All in all, the present study did not accuse that what the Indonesian memetic community had done is absolutely wrong but the researcher just wants to point out, fundamentally their idea will be rejected by other community unless they made their own rules in managing the memetic contents.

One of the primary limitation of the present research lies in the unit of the data. The researcher had taken only 50 samples from each meme since there are countless memes in the internet, and it is not possible to analyze them all. Thus, the researcher focuses on memes tended to be violated.

Moreover, the subjectivity of the researcher affects the result and formulation of the conclusion which is colored by researcher cultural and linguistic background. For that reason, the potential blind-spot in the present study is the low of in-depth observation in memetic society to create stronger evidence.

\section{Conclusion and Suggestion}

The researcher insisted at the beginning of the article that the indecent usage of 3 types of memes is caused by cultural diversity. However, the findings that researcher had found, suggest that the ignorance of meme function also become the reason. The cultural diversity factor can be divided into several sub-aspects such as the diversity of sense of humor, the age of meme audiences and creators, and also the popular events which recently happened in the society.

Current theories and research in the findings related to discourse analysis, specifically in memetic society, have to be explored further. This is to broaden the scope so as to reveal and verify what the researcher had missed in the current study. In terms of language pedagogical practices, a meme can be exploited to assist in the teaching-learning process.

\section{References}

Ali, A. J., Karen, V. d., \& Sanders, G. (2003). Determinants of Intercultural Adjustment among Expatriate Spouses. International Journal of Intercultural Relations 27, 563 - 580.

Arifin, Z., \& all, e. (2012). Teori dan Kajian Wacana Bahasa Indonesia. Jakarta: PT Pustaka Mandiri.

Azar, B. S. (1999). Understanding and Using English Grammar (second edition ed.). New Jersey: Prentice Hall.

Blackmore, S. (1999). The Meme Machine. New York: Oxford University Press.

Brunnello, \& Juliana. (2012). Internet-memes and everyday-creativity: Agency, sociability, and the aesthetics of postmodernism. Rotterdam: Erasmus University Rotterdam.

Chandler, D. (2012). Meme World Syndrome: A Critical Discourse Analysis of The First World Problems and Third World Success Internet Memes. Electronic Theses and Dissertations.

Dawkins, R. (2006). The Selfish Gene (original work published 1976 ed.). New York: Oxford University Press.

Distin, K. (2005). The selfish meme: A critical reassessment. New York: Cambridge University Press.

Erdodi, L. A., \& Lajiness-O'Neill, R. (2012). Humor perception in bilinguals: Is language more than a code? . Journal of Cross-Cultural Psychology. 
Fairclough, N. (2003). Analysing discourse. New York: Routledge.

Lesmana, M. (2014). Finding Out the Characteristic of Children's Humor in Indonesia. International Journal of Humanities and Social Science, IV (10), 91-100. Retrieved April 5, 2018, from www.ijhssnet.com/journals/Vol_4_No_10.../12.pdf.

Neil, G. M., \& Erin, S. (2013). Sense of Humor across Cultures: A Comparison of British, Australian and American Respondents. Retrieved April 05, 2018, from https://www.questia.com/library/journal/1G1331348552/sense-of-humor-across-cultures-a-comparison

Shifman, L. (2014). Memes in Digital Culture. Cambridge: The MIT Press.

Usia Produktif Mendominasi Pengguna Internet - Databoks. (n.d.). (n.d.). Retrieved April 05, 2018, from https://databoks.katadata.co.id/datapublish/2018/02/23/usia-produktif-mendominasi-penggunainternet

Yip, J. A., \& Martin, R. A. (2006). Sense of humor, emotional intelligence, and social competence. Journal of Research in Personality, XL(6). doi:10.1016/j.jrp.2005.08.005 